\title{
AYAT SUCI LENYEPANEUN AND SOCIAL CRITIQUES Moh. E. Hasim's Critiques of the Political Policy of the New Order
}

\author{
Ahmad Ali Nurdin, Jajang A. Rohmana \\ UIN Sunan Gunung Djati, Bandung - Indonesia \\ Corresponding author: ali.nurdin@uinsgd.ac.id
}

\begin{abstract}
One of the main objectives of the tafsir (Quranic interpretation) is to explain its Quranic contents to readers. In fact, tafsir also demonstrates an interaction between writers of tafsir and their socio-context where they lives. In Sundanese region, Moh. E. Hasim also criticised the New Order's policies when he wrote his tafsir called Ayat Suci Lenyepaneun. What are his critiques? How did he make critiques when at the same time he was writing the tafsir? How was his critique's position among socio-discourses that appeared in the Muslim world? Through the discourse-analysis approach, this study argues that Hasim's comments on the New Order's policies in his Lenyepaneun tafsir demonstrate a dialectical process of the interpreter (writer) with the socio-political context, which he faced. The texts' critiques of Hasim to the issue of gambling (Porkas and SDSB) and banning of veil demonstrated Hasim's challenge to the government's hegemony, which was very repressive. Hasim has successfully combined varieties of 'horizons', one being himself as a writer, the socio-political horizon and the horizon of the readers. Hasim's tafsir has not only displayed the socio-political situation of the society at that time but also became his tool to deliver his critiques.
\end{abstract}

Keywords: Tafsir, Sundanese, politic, the New Order.

\section{Introduction}

In recent years, Quranic exegesis (tafsir) written in local languages has been attracting more and more attention in the academic world, particularly among Indonesian scholars who study Quran. This is reflected by the growing literature on local Quranic tafsir during the last 
decade, including tafsir written in Javanese, Sundanese, Bugis and others. ${ }^{1}$ This trend seems to show that scholars who study Quran and the Quranic interpretation tried to adjust and negotiate between the "big tradition" and a Nusantara local tradition of tafsir. ${ }^{2}$

West Java is one of the provinces in Indonesia that produced a myriad of Quranic exegesis written in the local language. The second largest ethnic group in Indonesia, Sundanese, has been living in this province. This ethnic group speaks Sundanese as their mother tongue. One argues that there are thirty Quranic translations that have been published since the early twentieth century and half of them are tafsir written in Sundanese. ${ }^{3}$

One of the Sundanese tafsir that significantly affected the Sundanese Muslim society is a tafsir called Ayat Suci Lenyepaneun. This tafsir was written by Moh. E. Hasim (1916-2009). The tafsir is important for the Sundanese society because it is the only comprehensive tafsir (thirty volumes) written in the Sundanese local language. The popularity of the tafsir can be seen from the fact that this book has been reprinted for more than eleven times since 1984. Moh. E. Hasim, the tafsir's writer, is a Muhammadiyah's activist in Bandung who has been awarded the Rancage Literature Award in 2001, a prestigious award for a writer who published his work in a local language. ${ }^{4}$

\footnotetext{
${ }^{1}$ M. Muchoyyar HS, "Muhammad Shalih Al-Samarani: Studi Tafsir Faid Al-Rahman fi Tarjamah Tafsir Kalam Malik Al-Dayyan," Unpublished Doctoral Thesis, UIN Sunan Kalijaga, Yogyakarta (2000); Akhmad Arif Junaidi, "Tafsir Al-Qur'an Al-Azhim Karya Raden Pengulu Tafsir Anom," Unpublished Doctoral Thesis, IAIN Walisongo, Semarang (2012); Imam Muhsin, "Tafsir Al-Qur'an dan Budaya Lokal: Nilai-nilai Budaya Jawa dalam Tafsir Al-Huda Karya Bakri Syahid,” Unpublished Doctoral Thesis, UIN Sunan Kalijaga, Yogyakarta (2008); Sulaiman Ibrahim, “Tafsir Al-Qur'an Bahasa Bugis: Vernakularisasi dalam Kajian Tafsir al-Munir," Unpublished Doctoral Thesis, UIN Syarif Hidayatullah, Jakarta (2012); Jajang A Rohmana, "Nilai Budaya dalam Tafsir Al-Qur'an Berbahasa Sunda," Unpublished Doctoral Thesis, UIN Sunan Gunung Djati, Bandung (2013).

2 Robert Redfield, Peasant Society and Culture, An Anthropological Approach to Civilization (Chicago: The University of Chicago Press, 1956), p. 70. Fiona Bowie, The Anthropology of Religion: An Introduction, (Oxford: Blackwell Publishers, 2001), p. 25.

3 Jajang A Rohmana, "Perkembangan Kajian Al-Qur'an di tatar Sunda: Sebuah Penelusuran Awal," Jurnal Subuf, 6, 1 (2013), pp. 197-224.

${ }^{4}$ Her Suganda, "Moh. E. Hasim, Berkarya Sampai Tua," Kompas, 13 July (2004), p. 24. Ajip Rosidi (ed.), Ensiklopedi Sunda, Alam, Budaya, dan Manusia (Jakarta: Pustaka Jaya, 2000), p. 266.
} 
What the general public in Indonesia does not know, however, is the fact that Hasim was caught by police soon after he published his works, particularly the tafsir Ayat Suci Lenyepaneun, from 1989 to $1994 .{ }^{5}$ Hasim was accused of being too critical of the political and religious policies of Soeharto's regime in his speeches and writings. Soeharto's New Order Era (1966-1998) was well known by Indonesians and others as an authoritarian regime regarding the political policies. In his tafsir Lenyepaneun for example, Hasim strongly criticized the New Order's policies that legalized lottery under the name of social donation called Porkas (forecast) and Sumbangan Dana Sosial Berhadiah (SDSB/Social fund Donation Prizes). The ulama's fatwa, on which Soeharto's policy was based, was also criticized by Hasim when he interpreted the Quran chapter Al-Baqarah [2], verse 219 related to the drawing activity. ${ }^{6}$ In addition, Hasim also criticized Soeharto's policy to ban Muslims from wearing the hijab when he explained Quranic interpretation on chapter Al-Baqarah [2]: verse 132.7

This paper analizes Hasim's responses and critiques of New Order policies on religious issues in Indonesia. The key questions this study specifically proposes to address are: what were the political-policies of Soeharto's New Order on religious issues? Who is Hasim and what are his tafsiz's characteristics? How did Hasim criticize the New Order's policies on religious issues in his tafsit? What is the position of tafsir Ayat Suci Lenyepaneun in the discourse of social critique through tafsir in the Muslim world?

The study of Hasim's critiques of the Soeharto's policies related to religious issues in his tafsir is important due to several reasons. Firstly, this study could play a significant impact in showing that Quranic exegesis does not only consist of Quranic teachings that should be delivered to Muslim readers, but also demonstrates that there is a dialectical process between text and context on socio-religious dynamic faced by the interpreters. In Woodward's opinion, the text of tafsir could have a significant role as a tool to make an analysis of the socio-

\footnotetext{
${ }^{5}$ Interview with Halimah (66 years old), third daughter of Hasim, Bandung, 6 February 2017.

${ }^{6}$ Moh. E. Hasim, Ayat Suci Lenyepaneun (Bandung: Pustaka, 1994), vol. I, p. 296; vol. II, pp. 251-252; vol. III, p. 81.

${ }^{7}$ Hasim, Ayat Suci Lenyepaneun, vol. I, p. 302.
} 
religious situation in which the tafsir existed. ${ }^{8}$ In other words, the tafsir shows the "social commentary" of the interpreter to social changes in particular places and times. ${ }^{9}$ It is important to note that there should be a relation between the dynamics of the socio-political context around the interpreter and the product of tafsir. In terms of the tafsir methodology, the Lenyepaneun tafsir could be considered as an appropriate example of tafsìr adabi ijtimá $\bar{\imath}$ available in West Java. ${ }^{10}$

Secondly, the importance of this study could also be seen from the fact that Hasim wrote his Tafsir and made strong critiques in his mother language, the Sundanese local language. ${ }^{11}$ Hasim's interpretation of the Quran in local language, did not only try to 'domesticate' and build 'the bridge' of language diglossia between Quranic language and Sundanese language, ${ }^{12}$ but also delivered critiques in order to span between holy messages of God and locality and social context around the Quranic readers. This critique sometimes is considered as "a periphery" when compared to the critique written by Syu'bah Asa who delivered it through tafsir written in Bahasa Indonesia or the critiques delivered by political elites during Soeharto's regime. ${ }^{13}$ The critiques of Hasim are important to be discussed in order to show that there are a myriad of Muslims' groups unsatisfied with the Soeharto's policies, even among people located in the fringe region such as the Sundanese areas.

Thirdly, Hasim and his tafsir put up intellectual resistance to the hegemony of political and social power of the New Order. Hasim seems to follow the same steps of several Quranic interpreters in the world, such as critiques of Rashīd Rị̣ā and Muhammad 'Abduh in

\footnotetext{
${ }^{8}$ Mark R. Woodward, "Textual Exegesis as Social Commentary: Religious, Social, and Political Meanings of Indonesian Translations of Arabic Hadith Texts," The Journal of Asian Studies, 52, 3 (1993), p. 565.

9 Wan Sabri Wan Yusof, "Hamka's Tafsir al-Azhar: Qur'anic Exegesis as a Mirror of Social Change," Unpublished Ph.D. Thesis, Temple University, Philadelphia (1997), p. 36.

${ }^{10}$ M. Quraish Shihab, Membumikan Al-Qur'an (Bandung: Mizan, 1996), p. 68.

11 Jaja Zarkasyi, "Bahasa Sunda dalam Penafsiran Al-Qur'an,” Unpublished Master Thesis, UIN Syarif Hidayatullah, Jakarta (2009), p. 128.

12 Benjamin G. Zimmer, "Al-'Arabiyyah and Basa Sunda: Ideologies of Translation and Interpretation among the Muslims of West Java," Studia Islamika, 7, 3 (2000), p. 31.

${ }^{13}$ Islah Gusmian, “Tafsir Al-Qur'an dan Kritik Sosial: Syu'bah Asa dalam Dinamika Tafsir Al-Qur'an di Indonesia,” Maghza, 1, 2 (2016), pp. 67-80.
} 
their tafsì, Al-Manār (this tafsir influenced tafsì Al-Az̧ar written by Hamka); resistances of Sayyid Quṭ to the ruling government in Egypt through his tafsir Fi Zilal al-Qur'an; or critiques of Ahmad Sanusi on the Dutch colonial's policies through tafsir Malja' al-Täibin. ${ }^{14}$ Thus, it can be assumed that tafsir s written under social and political pressures mostly consist of critical discourse to the ruling government or the authoritarian regime.

Forthly, in the global perspective, the study of local tafsir s such as the Lenyepaneun tafsir is important to counter balance the study of tafsir in the heterogeneous and dynamic Muslim world. Currently, the study of tafsir could not only focus on tafsirs written by Middle Eastern scholars but also on the ones written by Muslim scholars living in Southeast Asian countries, particularly in the Indonesian Archipelago which is popularly known as the centre of Nusantara Islam..$^{15}$ The term so called Islam Nusantara is currently promoted by Indonesian scholars to instill a regional characteristics of Islam outside the Middle Eastern countries. ${ }^{16}$

Several scholars actually have been examining this Lenyepaneun tafsir. Their analysis, however, focused on theological themes and several aspects of Sundanese culture. The study of Suhendar, Iskandar, Alifah and Nurlaela for example, discussed the Lenyepanen tafsir from the theological perspectives, especially Hasim's interpretation on Quranic verses on theology, shirk (polytheism) and the meaning of infidel. ${ }^{17}$ They seem to show the militancy of Hasim in combating a

14 Al-Sayyid Muhammad Rasyid Ridha, Tafsir al-Qur'an al-Hakim al-Musytahar bi ism Tafsir al-Manar (Cairo: Mansya al-Manar, 1947); Sayyid Quthb, Fi Zhiläl al-Qur'an, (Beirut: Dar al-Syuruq, 1988); Ahmad Sanusi, Malja' al-Thälibin, Tapsir Bahasa Soenda, No 1-28. Tanah Tinggi Senen No. 191 Batavia Kramat, (1931/1349 H); Hamka, Tafsir al-Az̧har (Jakarta: Pustaka Panjimas, 1983).

15 Ziauddin Sardar, “The Future of Islamic Studies," Islamic Culture, 57 (1983), p. 197; Ahmad Rafiq, "The Reception of the Qur'an in Indonesia: A Case Study of the Place of the Qur'an in a Non-Arabic Speaking Community," Unpublished Ph.D Thesis, Temple University, Philadelphia (2014), p. 10.

16 Azyumardi Azra, "Islam Nusantara: Islam Indonesia," Republika, 25 June (2015), p. 12; Gwenael Njoto-Feillard, "Ripples from the Middle East: The Ideological Battle for the Identity of Islam in Indonesia," Perspective Vol. 42, (2015), pp. 1-10.

${ }^{17}$ Suhendar, "Penafsiran Moh. E. Hasim terhadap Ayat-ayat Syirik Samar dalam Tafsir Lenyepaneun," Unpublished BA Thesis, UIN Sunan Gunung Djati, Bandung (2004); Megah Iskandar, "Tema Tauhid dalam Tafsir Ayat Suci Lenyepaneun karya Moh. E. Hasim," Unpublished BA Thesis, UIN Sunan Gunung Djati, Bandung (2007); Laily Alifah, "Pandangan Moh. E. Hasim Mengenai Syirik dan Unsur-unsurnya dalam 
false theology or ideology. The interest of Modernist Islam in Lenyepaneun tafsir has been comprehensively examined by Rohmana. He compares the bias of ideological interest of Modernist Islam in Lenyepaneun tafsir and other Sundanese Nurul-Bajan tafsir written by Mhd. Romli and H.N.S. Midjaja. The ideological interest of the tafsir, at least could be seen from the introduction of the tafsir in which it criticized the traditional Islam and the syncretic culture practiced by the Sundanese community. ${ }^{18}$

Other studies on Lenyepaneun tafsir focused on the Sundanese culture. For example, the study of Zarkasyi and Laraswati showed that Lenyepaneun tafsir could be seen as a prototype tafsir aimed at extending the function of the Sundanese language. Through Sundanese tafsir, several aspects of Sundanese culture were easily adapted and inserted into the Quranic exegesis's explanation. For example, the hierarchical structure of the Sundanese language called undak usuk basa was used in Lenyepaneun tafsir as part of the Sundanese politeness-cultures. ${ }^{19}$ Another study examined Hasim's opinion in understanding Quranic verses related to education and ethics. This study did not only discuss the educational values of the Quran but also uncovered the educational values persisted from Sundanese-local cultures as explained by Hasim in his Lenyepaneun tafsir. ${ }^{20}$

In terms of social-critiques and reflection of social reality, Muslim scholars have written several tafsirs explaining the socio-political context in which the writers made critiques. Among those tafsir are $\mathrm{Al}$ -

Budaya Sunda," Unpublished BA Thesis, UIN Sunan Gunung Djati, Bandung (2016); Aan Nurlaela, "Makna Kafir Menurut Para Mufasir Indonesia (Studi Analisa Tafsir Moh. E. Hasim, Hasbi Ash-Shiddieqy, Quraish Shihab)," Unpublished BA Thesis, UIN Sunan Gunung Djati, Bandung (2016).

18 Jajang A Rohmana, "Ideologisasi Tafsir Lokal Berbahasa Sunda: Kepentingan IslamModernis dalam Tafsir Nurul-Bajan dan Ayat Suci Lenyepaneun," Journal of Qur'an and Hadith Studies, 2, 1, (2013), pp. 125-154.

19 Jaja Zarkasyi, "Bahasa Sunda dalam Penafsiran Al-Qur'an," Unpublished Master Thesis, UIN Syarif Hidayatullah, Jakarta (2009), p. 32; Nadia Laraswati, "Budaya Sunda dalam Tafsir Ayat Suci Lenyepaneun Karya Moh. E. Hasim,” Unpublished BA Thesis, UIN Sunan Gunung Djati, Bandung (2016).

20 Teten Rosyadi, "Tafsir Ayat-Ayat Pendidikan dalam Kitab Tafsir Berbahasa Sunda: Sebuah Kajian terhadap Tafsir Ayat Suci Lenyepaneun Karya Moh. E. Hasim," Unpublished BA Thesis, Universitas Ibnu Khaldun, Bogor (2014); Rifki Taufiq Qurrahman, "Pembinaan Akhlak Anak Perspektif Al-Qur'an (Penafsiran Moh. E. Hasim Surat Luqman Ayat 13-19)," Unpublished BA Thesis, UIN Sunan Gunung Djati, Bandung (2016). 
Manār written by Muḥammad Rashid Rị̣a, Fì Zilal Al-Qur'ān by Sayyid Quțb, Al-Az̧har written by Hamka and Malja' al-Tälibin written by Ahmad Sanusi. The study on Al-Manār tafsir has been conducted by several Indonesian Muslim scholars such as Shihab, Azra, and Burhanudin who admitted that there is a significant influence of $\mathrm{Al}$ Manär tafsìr on the transmission of reformation in Indonesia, as can be seen in the writing of tafsir $A l$-Az̧har by Hamka. ${ }^{21}$ The studies on $F \bar{\imath}$ Zilal al-Qur'ān tafsir (written by Sayyid Quṭ) have also shown that Quṭb's activities in Ikhwānul Muslimīn's movement (Muslim Brotherhood's movement) in Egypt have significantly impacted on his tafsir. Shepard, Nettler and Afif Muhammad who studied Quṭb's tafsir argued that Qutb's theological belief has importantly affected his ideological movement as can be seen from his tafsir. ${ }^{22}$ Like Quṭ's tafsìr, the tafsir Malja'a al-Talibin showed Sanusi's critiques of Dutch colonial policies. This means that the socio-political context where the tafsir writers lived has significantly influenced their work in Quranic interpretation. ${ }^{23}$

21 Quraish Shihab, Studi Kritis Tafsir al-Manar (Bandung: Pustaka Hidayah, 1994); Azyumardi Azra, "The Transmission of al-Manar's Reformism to the MalayIndonesian World: The Case of al-Imām and al-Munir," Stephane A. Dudoignon, Komatsu Hisao, and Kosugi Yasushi (eds), Intellectuals in the Modern Islamic World (New York: Routledge, 2006), pp. 143-158; Jajat Burhanudin, "Aspiring for Islamic Reform: Southeast Asian Requests for Fatwà in al-Manär," Islamic Law and Society, 12, 1 (2005), pp. 9-26; M. Yunan Yusuf, Corak Pemikiran Kalam Tafsir al-Azhar (Jakarta: Pustaka Panjimas, 1990); Wan Sabri Wan Yusof, "Hamka's Tafsir al-Azhar: Qur'anic Exegesis as a Mirror of Social Change," Unpublished Ph.D. Thesis, Temple University, Philladelpia (1997); Howard M. Federspiel, Popular Indonesian Literature of the Qur'an, Cornell Modern Indonesia Project, no.72 (Ithaca, New York, 1994); Mun'im Sirry, "What's modern about tafsir? A Closer look at Hamka's Tafsir al-Azhar," in Majid Daneshgar et.al., The Qur'an in the Malay-Indonesian World: Context and Interpretation, (New York: Routledge, 2016), pp. 198-211; Milhan Yusuf, "Hamka's method in interpreting legal verses of the Qur'an," in Abdullah Saeed, ed., Approaches of the Qur'an in Contemporary Indonesia, (London: Oxford University Press in association with the Institute of Ismaili Studies, 2005), pp. 42-66.

22 Nettler, Ronald. "A Modern Islamic Confession of Faith and Conception of Religion: Sayyid Quthb's Introduction to the Tafsir, Fi Zhilal al-Qur'an," British Journal of Middle Eastern Studies 21, 1 (1994); William E. Shepard, "Sayyid Quthb's Doctrine of Jabiliyya." International Journal of Middle East, 35 (2003).

23 Jajang A. Rohmana, “Al-Qur'ān wa al-Isti'mār: Radd al-Shaykh al-Ḥājj Ahmad Sanusi (1888-1950) 'alá al-Isti' 'mār min Khilāl Tafsīr Malja' al-Ṭälibin," Studia Islamika, 22, 2 (2015), pp. 297-332. 
From the above explanation, it is clear that all tafsirs have been influenced by the socio-political background of the writers, which encouraged them to make socio-critiques. Thus, it is noteworthy that a tafsir does not only explain the content of the Quran to its readers, but it could also become a medium to make critiques to the social reality. This study could strengthen the previous studies on the relation between the tafsir and the socio-political background of the writers but with different context and focus that is a critique of Sundanese tafsir on the New Order's policies on religious issues. This study tries to show another side of Lenyepaneun tafsir that is Hasim's socio-religious critiques of the policies of Soeharto's regime.

In general, this study is a library research with a critical-discourse approach, particularly in analysing Hasim's critiques of the New Order's political-policies. An analytical-discourse analysis is used to delve into the internal-text mechanism in delivering the critical responses of tafsir's writer. This analysis, however, does not necessarily ignore the socio-religious context of the scripture and how the readers have understood this text. ${ }^{24}$

This study examines Ayat Suci Lenyepaneun tafsir written in the Sundanese local language by Moh. E. Hasim. Thus, the primary source of this research is the thirty-volume tafsir itself wich each volume consists of two hundred pages or more. All texts, focusing on Hasim's interpretation on Quranic verses related to his critiques of the New Order's policies, were read and analized. The secondary resources were collected by interviewing the big family of Hasim, both his children and grandchildren mostly living in Bandung. Other interviews have been conducted with Islamic leaders in Bandung and the official leaders of Muhammadiyah of Bandung branch where Hasim was actively involved during his life. This interview is important to understand Hasim's social-interaction with the community. To enhance the analysis, other Hasim's works were analized as well. ${ }^{25}$ In addition, other tafsir books in Sundanese written by other scholars were

\footnotetext{
${ }^{24}$ Eriyanto, Analisis Wacana, Pengantar Analisis Teks Media (Yogyakarta: LKiS, 2001), p. 7.

${ }^{25}$ Rupa-rupa Upacara Adat Sunda Jaman Ayeuna (Bandung: Pustaka, 1996); Hadis Penting Papadang Ati (Bandung: Pustaka, 1997); Ayat Suci dalam Renungan 30 Jilid (Bandung: Pustaka, 1998); Khatbah Shalat Juma'ah (Bandung: Pustaka, 2006).
} 
also used for comparison purposes. ${ }^{26}$ Other classic and modern tafsir book written in Arabic were also used as secondary resources to measure the accuracy of Hasim's interpretation due to the fact that Hasim's does not have an Islamic boarding school (pesantren) educational background. In order to analyze the data, we used an interactive model analysis which consists of three analysis components: data reduction, display data and conclusions. ${ }^{27}$

\section{The Characteristic of Sundanese Tafsir}

In general, tafsirs written in the Sundanese local language have been developed since the early $20^{\text {th }}$ century. This development could not be separated from the context of modernization and Islamic reformation in Indonesia which led to the improvement of Islamic book publication in the country. ${ }^{28}$ Several scholars with various socio and educational backgrounds responded to the above issues by writing the Sundanese tafsir. Thus, it is understandable that the social-identity of writers, publishers and audiences of Sundanese tafsir are not monolithic. The writing of Sundanese tafsirs was not dominated by Islamic scholars (ulama) with Islamic boarding school background (both kyai and santri). However, the tafsirs were written by Sundanese filologists and academic scholars for different purposes. This trend shows dynamics of the Islamic development in the early $20^{\text {th }}$ century of Indonesian Islam.

There are several Sundanese tafsir writers with a myriad of socialidentity backgrounds such as Haji Hasan Mustapa, Ahmad Sanusi, R.A.A. Wiranatakoesoema, Muhammad Anwar Sanuci, Mhd. Romli, Ahmad Makki and Muhammad al-Hasan. Hasan Mustapa, a writer of

\footnotetext{
26 Mhd. Romli and H.N.S. Midjaja, Nurul-Bajan: Tafsir Qur'an Basa Sunda, 1, N.V. Perboe (1966); Muhammad Romli, Al-Kitabul Mubin Tafsir Basa Sunda (Bandung: PT. Al-Ma'arif, 1991); Moehammad Anwar Sanuci, Gajatoel-Bajan Tafsir Qoer'an Basa Soenda (Garut: Madjlis Ahli Soennah Garoet, 1923); A. Hassan, Tafsir Al-Foerqan Tafsir Qer'an Basa Soenda, Djoeragan Mh. Anwar Sanuci and Djoeragan Mh. Doenaedi (eds.) (Bandung: Taman Poestaka Persatoean Islam, Januari 1929); Uu Suhendar, Tafsir AlRazi Juz 'Amma jeung Al-Fatibah, Kasaluyuan Surat, Ayat jeung Mufrodat (Tasikmalaya: Pustaka Al-Razi, 2011).

${ }^{27}$ Mathew B. Miles and A. Michael Huberman, Analisis Data Kualitatif: Buku Sumber tentang Metode-metode Baru (Jakarta: UI Press, 1992), p. 20.

${ }^{28}$ Deliar Noer, Gerakan Moderen Islam di Indonesia 1900-1942 (Jakarta: LP3ES, 1996), p. 97 and p. 103; Ajip Rosidi, Masa Depan Budaya Daerah, Kasus Bahasa dan Sejarah Sunda (Jakarta: Pustaka Jaya, 2004), p. 78.
} 
tafsir Quranul Adhimi, was popularly known as a bureaucratic ulama because after studying and living in Mecca for more than ten years, he returned to Indonesia and became the head of the religious court in Bandung and Aceh. In addition, Hasan Mustapa was also popularly known as a Sundanese filologist and a poet because he wrote several books on the Sundanese culture and poetry known as Sundanese dangding. ${ }^{29}$

Ahmad Sanusi was well known as an ulama who led an Islamic boarding school in Sukabumi West Java. He published several books on Islamic teaching written in Sundanese scripts called pegon. He also wrote several tafsir books written in Sundanese. He was a founder of Islamic organization called Al-Ittihadijatoel Islamijjah which later on became a popular Islamic organization in West Java known as a Persatuan Ummat Islam (PUI/ The Unity of Islamic Ummah). ${ }^{30}$ Like Sanusi, Ahmad Makki and Muhammad al-Hasan are two Sukabumi's kyai who continued developing the literacy tradition in Islamic boarding school and translated several Islamic books written in Arabaic into Sundanese language. 31

Another tafsir writer is Mhd. Romli (1889-1981) who was popularly known as a kyai from Islamic Boarding School of Haurkoneng in Garut, West Java. He was also a prolific Sundanese writer who published several Islamic books in Sundanese language. Among his books are tafsir of Nurul-Bajan and tafsir of Alkitabul Mubin which were written with H.N.S. Midjaja or mostly known as Jaksa Neneng Sastramidjaja (1903-1975). The content of these books show that the

29 Haji Hasan Mustapa, Qur'anul Adbimi Adji Wiwitan Qur'an Sutji, compiled by Wangsaatmadja (Bandung, 7 July 1920); Jajang A. Rohmana, "Ekspresi Lokalitas Tafsir Sufistik di Tatar Sunda: Qur'anul Adhimi Aji Wimitan Kitab Suci Haji Hasan Mustapa (1852-1930)," Al-Qalam, 32, 1 (2015), pp. 25-55.

30 See Dadang Darmawan, “Ortodoksi Tafsir: Respons Ulama terhadap Tafsir Tamsjiijatoel-Moeslimien Karya K.H. Ahmad Sanusi," Unpublished Doctoral Thesis, UIN Syarif Hidayatullah, Jakarta (2009); Jajang A Rohmana, “Al-Qur'ān wa al-Isti'mār: Radd al-Shaykh al-Hāàj Ahmad Sanusi (1888-1950) 'alá al-Isti'mār min Khilāl Tafsìr Mal'ja' al-Ṭalibin," Studia Islamika, 22, 2 (2015), pp. 297-332.

31 Ahmad Makki bin KH. Abdullah Mahfudz, Tarjamah Tafsir Al-Qur'an Al-'Ażim li Jaläluddīn Al-Suyūti wa Jaläluddìn Al-Maḥalli, vol. 1 (Sukabumi: Percetakan Al-Salafiyah, n.d.); Muhammad 'Abdullah bin Al-Hasan Caringin Sukabumi, Sa'adat Al-Darayn fi

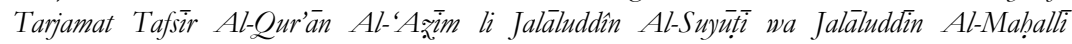
(Jakarta: Maktabah Dar Al-Hikmah, n.d).. 
writers were Islamic modern thinkers. ${ }^{32}$ The same tendency could also be seen in the tafsir of Gajatoel Bajan written by Anwar Sanusi. The writer was well known as a religious teacher at Leles Garut and an activist of the Islamic group called Ablus Sunnah Cilame (MASC). Besides writing a tafsir, Anwar Sanusi also translated several Islamic books written in Arabic into Sundanese, including tafsir of Al-Furqan. ${ }^{33}$

Sundanese tafsir books actually have been written not only by Islamic ulama but also by Sundanese filologist and poet. R.A.A. Wiranatakoesoema (1888-1965), for example, interpreted Quranic verses (Soerat Al-Baqarah) in a form of Sundanese poetry popularly known as dangding or guguritan. Wiranatakoesoema was popularly known as a Regent of Bandung (Bupati Bandung) who was also known as an expert in Sundanese culture and poetry. In addtition, a Sundanese filologist, Moh. E. Hasim (1916-2009), wrote a tafsir of Ayat Suci Lenyepaneun which is the focus of this study. Hasim was firstly wellknown as an Islamic religious teacher and a Muhammadiyah activist. His tafsir of Ayat Suci Lenyepaneun (1984) led him to be awarded the Rancage Award, a prestigious award for his meritorious service in maintaining Sundanese language through his writing. ${ }^{34}$ Another Sundanese tafsir writer with academic background was Uu Suhendar. He wrote a tafsir of juz' 'amma al-Razi (2010). Suhendar was known as a lecturer at the Islamic institution of Persatuan Islam (Persis). He graduated from the department of Arabic language from State Islamic University, Sunan Gunung Djati Bandung. ${ }^{35}$

There is a Sundanese tafsir written by several scholars with various social background called Tafsir Al-Qur'an Basa Sunda or Sundanese Quranic Tafsir (1978) that was published by the official government of the West Java province. This tafsir was called as a "project tafsir" because its writing was funded by the government of the West Java

32 Mhd. Romli and H.N.S. Midjaja, Nurul-Bajan: Tafsir Qur'an Basa Sunda, 1 (N.V. Perboe, 1966); Muhammad Romli, Al-Kitabul Mubin Tafsir Basa Sunda (Bandung: PT. Al-Ma’arif, 1991). See Jajang A. Rohmana, "Ideologisasi Tafsir Lokal Berbahasa Sunda: Kepentingan Islam-Modernis dalam Tafsir Nurul-Bajan dan Ayat Suci Lenyepaneun," Journal of Qur'an and Hadith Studies, 2, 1 (2013), pp. 125-154.

33 Moehammad Anwar Sanuci, Gajatoel-Bajan Tafsir Qoer'an Basa Soenda (Garut: Madjlis Ahli Soennah Garoet, 1923); A. Hassan, Tafsir Al-Foerqan Tafsir Qer'an Basa Soenda.

${ }^{34}$ Hasim, Ayat Suci Lenyepaneun.

${ }^{35}$ Uu Suhendar, Tafsir Al-Rari Juz 'Amma jeung Al-Fatihah, Kasaluyuan Surat, Ayat jeung Mufrodat (Tasikmalaya: Pustaka Al-Razi, 2011). 
province. ${ }^{36}$ The writers were a team consisting of ulama, academics, bureaucrats and filologists such as Anwar Musaddad, Yus Rusyana, Aboeng Koesman, Karna Suwanda, M. Syamsuddin, O. Djauharuddin AR, R. Totoh Abdul Fatah, Atjep Djazuli, Endang Soetari AD, and Wahyu Wibisana.

When we look at the audiences, the Sundanese tafsir was mostly written for teaching and learning purposes in several Islamic boarding schools. For example, the work of Ahmad Sanusi was used for teaching Islamic studies at Islamic boarding school or Pesantren Cantayan and Gunung Puyuh Sukabumi, West Java. Ahmad Makki's work was used at Pesantren Assalafiyah Babakantipar Sukabumi and Muhammad al-Hasan's tafsir was used by students (santri) at Pesantren Carigin Sukabumi.

In terms of script, language and method, Sundanese tafsir books vary as well. Roman scripts are mostly used by Sundanese tafsirs written in the post-independence period. Prior to the Indonesian independence, most Sundanese tafsirs were writtin in Sundanese script popularly known as a pegon script. In addition, the majority of Sundanese tafsir published before the Indonesian independence such as tafsir of Hasan Mustapa and Ahmad Sanusi, used general Sundanese language (loma language). Meanwhile, the Sundanese tafsir published after 1960s, mostly used more courteous Sundanese language, which is called as a lemes (polite language). This writing style seems to be influenced by the political policy of the Dutch colonial on Sundanese language in the early $19^{\text {th }}$ century. ${ }^{37}$

\section{Moh. E. Hasim and the Ayat Suci Lenyepaneun Tafsīr}

Moh. E. Hasim or Mohammad Emon Hasim was born in Ciamis, West Java on 15 August 1916. He was popularly known as a religious teacher and a tafsir writer. He could speak several foreign languages such as Arabic, English, Japanese and Dutch. He went to elementary school in his hometown and continued his studies in Schakelschool Muhammadiyah and HIS (Hollandsch-Inlandsche School) before going to MULO (Meer Uitgebreid Lager Onderwijs). Hasim attended

\footnotetext{
36 Anwar Musaddad et. al., Tafsir Al-Qur'an Basa Sunda, (Bandung: Proyek Penerbitan Kitab Tafsir Al-Qur'an Basa Sunda Jawa Barat, published by CV. Angkasa, 1991), vol 1, p. vii.

37 Thamrin Gunardi and E. Juhana Wijaya, Perkembangan Pendidikan di Jawa Barat dari Zaman ke Zaman (Bandung: Armico, 1997), pp. 55-59.
} 
AMS (Algemeene Middelbare School) but did not complete his study due to the case of malaise in 1930s. He learned languages and Islamic studies autodidactically. He became a teacher at several schools such as HIS Pasundan, Schakelschool Muahmmadiyah and Schakelschool Islam Miftahul Huda. Furthermore he even became the head of school at Miftahul Huda.

During the Japanese colonial period, Hasim had become a teacher at Sekolah Rakyat (People School/Kokumin Gakkoo) before he became an administrative staff called Boei Karicho at the District Office (Kantor Kabupaten). In this office, he also became an interpreter. After the Indonesian independence, Hasim participated in establishing an embryotic Indonesian Armed Force called Barisan Rakyat (BARA), Badan Keamanan Rakyat (BKR) and Tentara Keamanan Rakyat (TKR) in Ciamis, West Java. Hasim was appointed as a head of Persatuan Perjuangan Nasional, which was a joined armed forces of Sabilillah, Hizbullah, Tentara Pelajar and BBRI. Due to his activities, Hasim had been caught several times by the Dutch officers and had been given home detention in Ciamis before he escaped to Bandung. In Bandung, due to his expertise in English language, Hasim tought at several high schools and universities such as IKIP B. SATKA (DKA) and Akademi Niaga. He also wrote several English text books for elementary and high school students. He was the head of Muhammadiyah branch office at Cicendo-Bandung.

Upon retirement, Hasim continued his intellectual journey by selflearning Islamic teachings and learned Arabic autodidactly which led him to write religious books in Sundanese including his monumental work, Lenyepaneun Tafsir (1990-1993). For his works, Hasim got an award from the Cultural Institute of (Lembaga Kebudayan) UNPAS (Pasundan University) in 10 April 1994 and was awarded a prestigous Sastra Rancage Award in 31 Janury 2001 for his achievement writing several books in Sundanese. Hasim passed away in Hasan Sadikin Hospital on 3 May 2009. He died at the age of 93 and was survived by his ten children. ${ }^{38}$

Besides his monumental work Lenyepaneun Tafsir, Hasim also wrote several books such as Grammar and Exercises, Kamus Istilab Islam, Ruparupa Upacara Adat Sunda Jaman Ayeuna (Bandung: Pustaka, 1996), Hadis

38 Interview with Halimah, 13 March 2012. See also Suganda, "Moh. E. Hasim, Berkarya Sampai Tua; Ajip Rosidi (ed.), Ensiklopedi Sunda, Alam, Budaya, dan Manusia (Jakarta: Pustaka Jaya, 2000), p. 266. 
Penting Papadang Ati (Bandung: Pustaka, 1997), Ayat Suci Lenyepaneun 30 Jilid (Bandung: Pustaka, 1984), Ayat Suci dalam Renungan 30 Jilid (Bandung: Pustaka, 1998), Iqra (Bacaan dan Tulisan), Khatbah Shalat Juma'ah (Bandung: Pustaka, 2006).

According to Hasim, his motivation for writing Lenyepaneun tafsir was foremostly encouraged by his interest to dig a main source of Islamic teaching, the Quran. His interest to scrutinize Islamic teachings appeared when he has been a teacher in 1970s. Hasim has tried to buy several Quranic translation books in Indonesian at that time to understand Quran, but he was unsatisfied. He even bought a Quranic tafsir written in Indonesian by a famous Islamic scholar (ulama) at that time, but he was still not convinced. He complained about the Quranic tafsir he read by saying: "Bob metodeuna boh éntép seureubna teu ngajembarkeun panalar santri tingkat pre-elementary" (both method and structure of the tafsir were imperfect and could not clearly inform the real meaning of the Quran for the beginners). For that reason, Hasim tried himself to start interpreting Quranic verses and write the tafsir. He wanted it to be a present for his $70^{\text {th }}$ birthday for his children, grandchildren and his big family. ${ }^{39}$

$\mathrm{He}$ firstly wrote tafsir chapter Al-Baqarah in Indonesian. He distributed several copied of his writing to colleagues, families and friends in Bandung and Ciamis. Six months later, a Kyai from Ciamis (Kyai Adnan) came to visit Hasim and told him that the tafsir written by Hasim was very interesting and helpful as a source for Islamic teaching in Islamic boarding school. Kyai Adnan then asked Hasim to continue his tafsir writing and suggested to write it in Sundanese local language instead of Indonesian. Hasim tried to reject Kyai Adnan's request by putting it humbly that he was not an Islamic scholar and did not have any Islamic boarding school's background to keep writing the tafsir. Due to Kyai Adnan's suggestion to help enlightening Muslim community, however, Hasim finally agreed to continue writing the tafsir. With his encouragement and eagerness, Hasim kept writing his tafsir Lenyepaneun in Sundanese. ${ }^{40}$

39 Moh. E. Hasim, "Pangalaman Nyusun Naskah Ayat Suci Lenyepaneun," Perhimpunan Keluarga Besar Pelajar Islam Indonesia (Perhimpunan KB-PII), Ngamumule Budaya Sunda Nanjeurkeun Komara Agama, Lokakarya Da'wah Islam Napak Kana Budaya Sunda (Bandung: Perhimpunan KB-PII, 2006), p. 87. See also Moh. E. Hasim, Rupa-rupa Upacara Adat Sunda Jaman Ayeuna (Bandung: Pustaka, 1996), p. v.

${ }^{40}$ Hasim, "Pangalaman Nyusun Naskah Ayat Suci Lenyepaneun, p. 87. 
When Hasim completed one Juz out of thirty Juz of the Quran, he asked a publisher to publish his work but it was rejected. He felt discouraged and hesitated to continue writing the rest of the tafsir. Hasim then remembered the wise words saying that "where there is a will there is a way" and the other wise word: "though you stumble off, never be down cast, try and try again, you'll succeed at last, and he kept writing the tafsir until finishing the second Juz of the Quran. After finishing two Juz, Hasim asked another publisher, Pustaka Salman ITB, to publish his writing. The Pustaka publisher agreed to publish Hasim's work but asked Hasim to at least write three Juz of the Quran. Hasim was very happy and he wrote another juz to fulfil the publisher's request. Finally, Hasim's work was firstly published and distributed to the public in 1989. Hasim's book was welcomed by the readers and in short time this Lenyepaneun tafsir was sold out. Although Hasim has been sick for four months during writing the tafsir, he finally completed all thirty juz of the Quranic tafsir and he even kept writing another Indonesian tafsir called Ayat Suci dalam Renungan. ${ }^{41}$

Every day, after performing midnight prayer (Tabajud) at $02.30 \mathrm{am}$, Hasim kept writing the tafsir using an old typewriter for several years. He admitted that each juz of the Quran needs at least four months to write. ${ }^{42}$ When he was writing the tafsir, he often reflected and thought the relevancy of the Quranic verses he interpreted with the socialconditions or the context. He did so, because according to Hasim, there were so many Quranic verses that should be interpreted by looking at the political, economic, scientific and theological approaches as well as the contextual background of the text (asbäb al-nuziñ) why these Quranic verses were revealed to the Prophet Muhammad. When Hasim found the meanings of the Quranic verses he interpreted, then he looked for the appropriate sentences to be adequately used in his tafsir in order for his writings to be easily accepted by the heart of the readers. In his Sundanese words, Hasim said that the sentences he used should nyerep kana angen sumarabah kana bayah (be accepted and embedded in the heart). "For me, the most important thing is the soul of the sentences that should be undertood because the structure of Arabic language was different from Indonesian and Sundanese". Although he faced several obstacles in writing the Lenyepaneun tafsir,

\footnotetext{
${ }^{41}$ Ibid., pp. 88-89.

${ }^{42}$ Suganda, "Moh. E. Hasim, Berkarya Sampai Tua.
} 
due to his preservance and God's help, Hasim successfully completed all his writings. ${ }^{43}$

Ayat Suci Lenyepaneun could be considered as the first completed and published Quranic tafsir in Sundanese written in roman script. This tafsir was written in a very peculiar way, and was easily undertood by the readers. It consists of thirty volumes because each volume consists of one juz of the Quran. There are three or four hundred pages per volume.

One of the distinctions of Lenyepaneun tafsir was the fact that Hasim used contemporary events or social issues in the society that are relevant to the Quranic verses he interpreted. Thus, Hasim's interpretation seems to be very actual and popular among society. In its method, Hasim used rational approaches, which was popularly known in Quranic studies as a tafsir bi al-ra'y with a tablilil's method. This tafsir could be considerd as a Sunni tafsir and using community approaches or adab al-ijtimâ $\hat{\imath}$.

The structure of the Lenyepaneun tafsir usually begins with the Quranic verses quotation (one or two verses) written in Arabic followed by roman script (non-Arabic) and after that translated into Sundanese. Each Arabic word then was translated into roman script, followed by interpretation and discussion of the meanings. If the verses interpreted were very long, Hasim divided his descriptions and discussions into several main themes.

In term of references, Hasim sometimes quotes the background of revelation (Asbäb al-Nuzūi) taken from the Hadith of the Prophet. Hasim, unfortunely, has never compared his explanation or interpretation with other Quranic tafsirs, both classic and modern standard tafsir. In several occasions, Hasim reinforced his explanation of the tafsir using modern science findings such as the science of astronomy. In his tafsir, Hasim never mentioned sources of references from tafsir written in Arabic. Hasim only admitted that he used the translated Quran in Indonesian and Sundanese dictionary as well as the book of Arabic teaching in English as his main references. ${ }^{44}$ Hasim's style in interpreting the Quran reminds the readers of the Hamka's style in writing his Al-Azhar's tafsir. Sundanese language used by Hasim was very communicative in the style which he tried to explain Quranic

\footnotetext{
${ }^{43}$ Hasim, "Pangalaman Nyusun Naskah Ayat Suci Lenyepaneun, p. 90.

${ }^{44}$ Ibid., p. 87. See also Hasim, Ayat Suci Lenyepaneun, vol. 11, p. v.
} 
verses in line with the Sundanese way of thinking. ${ }^{45}$ Lenyepaneun Tafsir was written by Hasim to maintain Sundanese language as well as his interest to comprehend Islamic teachings from its main sources, the Quran. In addition, Hasim was inspired by the Hadith of the Prophet Muhammad saying that it is a duty of all Muslims to deliver the right path of Islam even only one verse from the Quran to the society.46

Tafsir of Lenyepaneun was published in a period when Islamic publishers were mushrooming during the Soeharto's New Order era. The distribution of Hasim's tafsir was generally found in bookshops around Bandung. ${ }^{47}$ Although there were several traditional ulama questioning Hasim's authority in writing the tafsir due to his lacking the Islamic boarding school (Pesantren) background, Muslims in the urban areas, however, tended to welcome Hasim's work because the Lenyepaneun tafsir helped them to understand the Quran. They admitted that Lenyepaneun tafsir was using the daily language they used. ${ }^{48}$ Thus, a publication of Lenyepaneun tafsir was believed to be an important resource for Sundanese Muslim community in an urban area when they discussed Islamic teachings. The tafsir's publication was also considered by Sundanese community at that time to be a more effective way in delivering Islamic teachings compared to Islamic teachings delivered by the Islamic preacher through religious speeches (pengajian) at mosques particulary at the suburb areas in West Java. ${ }^{49}$

\section{Hasim's Critiques to the New Order Policies}

It is important to consider the socio-religious and political situation of a country in which a Quranic tafsir written. The Lenyepaneun tafsir was written in a New Order Indonesian political context. The New Order regime has been variously characterised by scholars. Despite

\footnotetext{
${ }^{45}$ Rosidi (ed.), Ensiklopedi Sunda, p. 71.

${ }^{46}$ Hasim, "Pangalaman Nyusun Naskah Ayat Suci Lenyepaneun, pp. 87-89.

${ }^{47}$ Martin van Bruinessen, "Kitab kuning; Books in Arabic script used in the Pesantren milieu; Comments on a new collection in the KITLV Library," Bijdragen tot de Taal-, Land- en Volkenkunde 146 (1990), no: 2/3, Leiden, p. 227.
}

48 See Howard M. Federspiel, Kajian Al-Qur'an di Indonesia: dari Mahmud Yunus hingga Quraish Shibab, trans. Tadjul Arifin (Bandung: Mizan, 1996), pp. 106-107.

49 The Muslims in Sundanese region generally like religious speeches delivered in Sundanese language. The preacher legend like KH. A.F. Ghazali (2001) was aware about significant and important positions of Sundanese language among the people that made him very popular among Sundanese. See Jullian Millie, The People's Religion, pp. 9-11. 
differences, the similarities, which can be used to characterise the New Order state, point to the regime as a military dictatorship. ${ }^{50}$ Robison, for example, argues that the striking characteristic of the New Order has been centralisation of power under Soeharto backed by the military. ${ }^{51}$ This situation has forced Indonesians, including tafsir writer to argue against government policies. Policies of the New Order seem to disadvantage Indonesian Muslim in the name of its propaganda's national stability. The New Order government made a hegemony over socio-political life on Indonesian Muslim. Gramsci (1891-1937) pointed out that to make a hegemony; the ruling class uses political leadership and ideology. In Gramsci's words, I quote:

“...the party, and particularly its leading intellectuals, are engaged in the struggle for ideological hegemony against the dominant influence of the bourgeois media, their control over the most powerful institutions of civil society - schools, religion, cinema and other artistic organizations". ${ }^{52}$

Indonesians, particularly Muslims, experienced the hegemonic power of the New Order. Soeharto's regime was very powerful and authoritarian. Soeharto used political and economic stability's reasons to oppress their opponents and oppositions. ${ }^{53}$ The regime imitated Dutch colonial policy which seemed to be tolerant to the Islam and Muslims, but strongly oppressed political Islam. ${ }^{54}$ The New Order regime built their political power, not only through the physical oppression, but also through construction of a harmony and acquiescent discourse among society. ${ }^{55}$

Several tafsirs written in Soeharto's era responded critically to the political situation of the regime. One of them is Lenyepaneun tafsir written by Hasim to respond to the New Order's policies particularly

50 Stefan Eklof, Indonesian Politics in Crisis: The Long Fall of Subarto 1966-1998 (Copenhagen: Nordic Institute of Asian Studies, 1999), p. 3.

51 Richard Robison, Indonesia: The Rise of Capital (Sydney: Allen and Unwin Pty Ltd., 1986), p. 105

52 Joseph Francese (ed.), Perspectives on Gramsci, Politics, Culture and Social Theory (New York: Routledge, 2009), p. 10.

53 Anthony Reid, Imperial Alchemy, Nationalism and Political Identity in Southeast Asia (Cambridge: Cambridge University Press, 2009), p. 70.

54 Robert W. Hefner, Civil Islam: Muslim and Democratization in Indonesia (Princeton and Oxford: Princeton University Press, 2000), p. 121.

55 Ariel Heryanto, Perlawanan dalam Kepatuhan (Bandung: Mizan, 2000). 
religious policies. The tafsir not only explains the meaning of the Quranic verses but also criticizes the political policies of the New Order authoritarian regime. Lenyepaneun tafsir responds to several social-religious issues debated by Indonesian Muslims during Soeharto's period. Among these issues are as follows:

\section{Critique on Gambling: Porkas and SDSB (Social Fund Donation Prizes)}

One of the most controversial issues during the New Order was a policy on government-sponsored soccer lotto, called Porkas (from English word Forecast) and its successor that went various names including Sumbangan Dana Sosial Berhadiah, SDSB (Social fund Donation Prizes). This Porkas tote was firstly legalized by the Ministry of Social and Ministry of Youth and Sport in 1986 in order to fund sports' facilities and to improve Indonesian sport's performances particularly the Indonesian soccer clubs. ${ }^{56}$ Robert Cribb notes the New Order government collected a huge amount of money from this policy and an amount of around 962 billions rupiahs has been collected in $1988 . .^{57}$

Indonesian Muslims at that time immediately resisted the policy and protests were organized throughout Indonesia. Many kyais and ulama all over Indonesia demanded a ban of Porkas. The two Muslim biggest organizations in the country, Muhammadiyah and Nahdhatul Ulama, proclaimed that Porkas is a form of gambling and therefore forbidden in Islam (haräm). Many kyais from several provinces in Indonesia requested the Soeharto's government to stop the program. The majority of the Indonesian Muslims then demanded the Ministry of Religious Affairs and Majlis Ulama Indonesia (MUI/ Indonesian Ulama Council)to clearly declare Porkas as a forbidden activity. MUI was asked to make an unambiguous statement about the porkas. MUI then sent an official letter to the government stating that the Porkas were negatively impacting the society and suggested the government to ban them. Unfortunately, the government rejected to disband them and paved the way for Muslims to organize bigger demonstrations.

\footnotetext{
56 Martin van Bruinessen, "Islamic state or state Islam? Fifty years of state-Islam relations in Indonesia," Ingrid Wessel (ed.), Indonesien an Ende des 20. Jabrbunderts, (Hamburg: Abera-Verag), p. 29.

${ }^{57}$ Robert Cribb and Audrey Kahin, Historical Dictionary of Indonesia (Lanham, Maryland, Toronto, Oxford: The Scarecrow Press, Inc., 2004), pp. 152-3.
} 
This issue became more controversial when the head of MUI Ibrahim Hosen, released a statement in defense of Porkas saying that what was forbidden in Islam called maisir or a face to face gambling was different from the Porkas. Hosen's statement led others so called independent ulama in Indonesia to argue aganst his argument. ${ }^{58}$ Of course, this Porkas affair has made the MUI lose its credentials among the Muslim community. However, when the government changed Porkas with another name called SDSB (Sumbangan Dana Sosial Berhadiah or Social Fund Donation Prizes) in 1990, like The Ikatan Cendekiawan Muslim Indonesia (ICMI/Association of Indonesian Muslim Intellectuals), MUI issued a fatwa that all kinds of lotteries are gambling and forbidden (harām) in Islam. Finally, Soeharto's government officially banned Porkas or SDSB in 1994. The Soeharto's policy about this issue showed that there was a significant change of Soeharto and the New Order's attitude toward the Muslim communities in the country. This means that Soeharto seems to make a u-turn in his last presidency period to have more positive attitude toward the Muslims. ${ }^{59}$

In response to this Porkas issue, Hasim is among writers who strongly criticised the New Order's policy promoting the Porkas or SDSB in Muslim majority country. When he interpreted Quranic verses under the gambling theme, particularly the chapter Al-Baqarah (2), verses 219 and 274; and chapter Al-Maidah (5) verse 90, Hasim argues:

...gambling is also dangereous. If we scrutinize the daily impacts of gambling, it led to several negative acts such as fighting, hostility, and killing among the gamblers themselves. During the Porkas era, there was a husband who burned his wife in North Sumatera and Buntoro, a Porkas agent in Tasikmalaya was killed by his gambling friend. The Porkas is also dangerous for a spiritual aspect or taubid (to worship God alone) and led to idolatry (shirk) acts such as visiting the shaman, asking help from Holy Spirits who live in the mountain or spring water. Even there was a funny and idiot act of the gambler to ask a crazy or mad man (orang gila)

\footnotetext{
${ }^{58}$ Martin van Bruinessen, "Indonesia's ulama and politics: caught between legitimising the status quo and searching for alternatives," Prisma-The Indonesian Indicator, 49 (1990), p. 64.

59 Delmus Puneri Salim, The Transnational and the Local in the Politics of Islam, (Switzerland: Springer, 2015), p. 140; R. William Liddle, "The Islamic Turn in Indonesia: A Political Explanation,” The Journal of Asian Studies, 55, 3 (1996), p. 614.
} 
to win tote. They ask a mad man and the interrogator is then crazier. ${ }^{60}$

\section{Hasim further explains:}

Please be aware not to buy SDSB in the name of giving charity; while in fact their purpose was to win and get huge amounts of money instantly, become suddenly a very rich man and become billioners. Such acts could be considered as a deception; to deceive God. Even a kid understands that giving a thousand rupiah and hope millions rupiahs in return; and let alone visiting a shaman and many times talking on your own and count in a paper hoping you will win the lottery; failing several times and finally suffering several losses and your trading has broken because the capital has been spent to buy a lottery coupon. ${ }^{61}$

Even the Porkas seems to have a good purpose to help poor people, in this chapter Al-Maidah verse 90, Allah has stricty forbidden gambling. For those who have money, it is forbidden (haram) to buy lottery. For poor people was also forbidden to spend lottery's money. Porkas and SDSB did not aim to help poor people but to make them poorer instead. Thus, gambling is worse their sin hereinafter compared to doing maysir. ${ }^{62}$

${ }^{60}$ The original version in Sundanese reads: ... dina ngadu oge sarua ngabahayakeun. Upama dijojoan nu nembrak sapopoe di antarana papaseaan, mumusuban, gelut jeung silih paehan. Dina jaman PORKAS, di Sumatra Utara aya jelema ngaduruk pamajikanana, sawatara taun ka tukang, Buntoro, raja KSOB di Tasikmalaya, ditelasan patina ku batur saprofesina. Mamala ngadu kana robani nyaeta syirik saperti dudukun, menta-menta ka lelembutan nu ngagengeub batu gede dina mumunggang gunung atawa di hulu cai. Malah aya nu matak hemeng jeung pikaseurieun, jalma walabwah-weuleubweuh kurang saeundan sok dijadikeun pananyaan, pokna teh: "Yeub bejakeun, nomer sabaraba?" Nu dipuntangan jelema nu teu eling atuh nu muntanganna mah bisa jadi leuwih kitu. Hasim, Ayat Suci Lenyepaneun, vol. II, pp. 251-252.

${ }^{61}$ The original version in Sundanese reads: Kade ulab meuli kupon SDSB bari akon-akon nyumbang, padahal maksud nu sabenerna hayang kadatangan jurig tumpak kuda, beunghar ngadadak ngantongan duit mangmilyar-milyar. Kalakuan kitu teh panipuan, rek nipu Allah jeung jalma-jalma nu ariman. Budak leutik ge ngartieun, piraku nyumbang sarebu bayang dipulang ratusan juta, komo ari ditambahan ku dudukun jeung mindeng kecewas-kecewis sorangan bari kutrat-kotret dina keretas salambar, euweub patlot panto pinub ku kapur atawa areng. Sakali moos dua kali luput, tungtungna balantik. leuleutikan gulung tiker, da modalna ledis dipake nyumbang bandar kupon. Hasim, Ayat Suci Lenyepaneun, vol. III, p. 81. See also vol., p. 296.

${ }^{62}$ The original version in Sundanese reads: Sanajan ngandung tujuan rek nulungan fakir miskin, dina ayat 90 ieu kalawan tegas diharamkeun. Nu baroga duit haram ngalakukeun ngaduna, nu miskin haram ngadahar hasilna. PORKAS jeung SDSB teu boga tujuan nulungan fakir miskin malah kalah ngamiskinkeun rakyat leutik, ku kituna pasti leuwih beurat tanggung jawabna batan maisir engke di alam aberat. Hasim, Ayat Suci Lenyepaneun, vol 7, p. 26. 


\section{Critique on Ulama who Supported New Order Policy on Gambling}

Hasim did not only criticize the New Order's policy on gambling but also blamed the MUI's member who supported the policy such as Ibrahim Hosen. In interpreting and explaining the chapter Al-Maidah verse 91, Hasim states:

This [verse 9] on gambling contains 'adäwata wa al-baghḍa $\vec{a}$ [resentment and hatred]. However, almost in every country in the world, liquor factory and gambling are allowed and not forbidden. It is confusing when someone put Islam as their religion in their ID card, but they are busy in establishing a lottery pool. It is said that they want to eradicate poverty, but in fact, they made a more impoverishment. It could be understood if lay people played gambling because they did not read the Quran and hadith yet. But, if the ulama or religious scholar supported Porkas or SDSB, it could not be understood at all. ${ }^{63}$

\section{Critique on Disbanding Wearing Veil (Jilbāb)}

Besides his critiques on gambling policy, Hasim in his Lenyepaneun tafsir also criticized Soeharto's regime who disbanded the wearing of jilbäb particularly for female students. The New Order regime banned students from wearing a new kind of long jilbab not the kerudung or headscarf. This wearing a new kind of jilbäb was popularized and promoted by young-da'wah network in the urban areas in several campuses and mosques. This kind of jilbäb was different from the one traditionally worn by NU and Muhammadiyah's members. This jilbāb became a provocative symbol to resist the New Order regime. Thus, according to Deni Hamdani, there were several public schools such as SMA 3 Bandung, SMAN 1 Jember, and SMPN 4 which stricty prohibited their students from wearing jilbäb. Several kinds of punishments then were applied to students wearing jilbäb in school, starting from exclusion from the class to encouragement to move to

${ }^{63}$ The original version in Sundanese reads: Ieu teb 'adawata walbagh-dhaa-a nu kannggel dina ayat di lubur. Tapi meh di unggal nagara pabrik inuman keras jeung alat ngadu benteu dilarang. Sakapeung sok matak. bingung ngabandunganana, ongkoh katepena Islam ongkoh cakahcikih nyieun parusahaan ngadu, cenah rek numpes kamiskinan tapi kalah ka nambahan kamalaratan. Keun atuh ari kaom awam mah, da meureun can maca Qur'an jeung Hadis, tapi upama ulama peujit koreseun milu balakecrakan murak SDSB, atawa ngabalalkeun PORKAS jeung SDSB kapan ieu mah matak teu kaharti leuwih ti misti. Hasim, Ayat Suci Lenyepaneun, vol 7, p. 30. 
other schools. Several campuses such as ITB in Bandung and Airlangga University in Surabaya also applied this policy. ${ }^{64}$ In addition, Soeharto's regime also required that a photo requirement on ID cards should be that of uncovering the ears. This means that females should put their julbäb off when taking a photo for the ID card.

Hasim criticised the government policy on disbanding wearing the hijäb when he interpreted and explained these Quranic verses: AlA'rāf/7: 102; Al-A'rāf/7: 169; Al-A'rāf/7: 175; Al-A'rāf/7: 201 and AlAnfāl/8: 39. Hasim said:

At this time, there are many impious people (fäsiq). For example, God has obliged the Prophet to instruct his wife and his daughters as well as all Muslim females to wear the julbäb (veil) as mentioned by God in the Quran chapter Al-Ahāāb verse 59. However, at this time, we found that many students wearing jilbāb have been expelled from their schools. Many students went to court asking for justice but they lost. There were even secular ulama who prohibited their families from wearing jilbäb. ${ }^{65}$

If we were brave to change the amount of inheritance as mentioned by God in chapter al-Nisa verse 11 (inheritance of a man is twice that of a woman) to be equal for both male and female, and then what we changed was followed and adopted by 1000 lay people, then our sin was multiplied by the sin of those 1000 people. Thus, it is the same case if we were brave enough to reject the obligation of God mentioned in the Quran chapter alAhyāb verse 59 on the obligation of wearing veil for Muslim females by saying that weiring jilbāb or veiling is not compulsory and jilbāb was an Arabic culture for Arabic women, then our sin

\footnotetext{
${ }^{64}$ Deny Hamdani, "The Quest for Indonesian Islam: Contestation and Consensus Concerning Veiling," Unpublished Ph.D Thesis, The Australian National University, Canberra (2007), pp. 52-60.

${ }^{6}$ The original version in Sundanese reads: Jaman kiwari ge teu saeutik golongan fasek teh, contona kieu: Allah SWT nimbalan Nabi saw supaya anjeunna miwarang geureubana, putrina, jeung kaom wanita nu ariman marake jilbab. Kitu nu kaunggel dina surat al-Akbzab (sic!) ayat 59 juz 22. Tapi para siswa SLTA nu marake jilbab dipecat ti sakolana. Aya nu merkarakeun hal ieu ka pangadilan, tapi nu dijilbab dinyatakeun eleh perkara. Malah aya ulama sekuler nu ngalarang kulawargana make jilbab. QS: Al-A'rāf/7: 102; Hasim, Ayat Suci Lenyepaneun, vol. 9, p. 38.
} 
will be multiplied by the sin of women who followed our argument. ${ }^{66}$

In Panji Masyarakat magazine number 585, 1-10 September 1988, it was said that the Shirian government banned female in the country from wearing jilbāb. Many lecturers in Shiria were fired because they rejected to remove their veil. Many students were also expelled from the schools. There has been instances in our country when many female students were expelled as well. And those who were anti- jilbāb were Muslims. What was very damaging, according to Hasim, was that there were many ulama professors who rejected and negated the Quran, particularly chapter al-Ahzāb verse 59 on veiling. One of them said jilbāb was imported from Saudi Arabia and there was not jilbab tradition in Islam. Another ulama said that jilbäb was to cover the chest not to cover the head because it is noted in chapter An-Nūr verse 31 that they (Muslim female) were ordered to cover their chest with the jilbāb. Why educated people and ulama professor did not understand the function of jilbab (veil). The meaning of the verse above was the order to cover the head up to chest of the Muslim female. ${ }^{67}$

${ }^{66}$ The original version in Sundanese reads: Lamun urang wani ngarobab hak waris anak lalaki jeung anake awewe nu kaunggel dina surat an-Nisa ayat 11, terus aturan meunang ngarekayasa urang digugu ku 1000 jelema kaom awam, dosa urang bakal ditambah ku jumlah dosa jelema nu 1000 urang. Sedeng dosa maranehna teu aya nu dicoceng. Nya kitu deui lamun urang wani ngabantah dawuban Allab SWT dina surat al-Abzab ayat 59, parentah make jilbab ka kaom wanita, ku ucapan: "Islam tidak. kenal jilbab. Jilbab dan kudung itu impor dari Timur Tengah. Wanita Arab diharuskan menutup aurat karena kaom prianya memandang wanita hanya sebagai sarana pelampiasan sex," nya dosa urang bakal ditambah ku sajumlah dosa jalma-jalma nu nurut ka urang. QS: Al-A’rāf/7: 169; Hasim, Ayat Suci Lenyepaneun, vol. 9, pp. 206-7.

67 The original version in Sundanese reads: Dina Panji Masyarakat No. 585 taun 1-10 September 1988, disebutkeun yen pamarentah Syria ngalarang kaom wanita make jilbab. Geus loba dosen nu dieureunkeun lantaran teu daraek. ngalesotkeun jilbab nya kitu deui murid-murid loba nu jadi korban. Padahal nu anti jilbab teh cenah ngagem agama Islam. Nu sarupa kieu teh di nagara urang oge kungsi kajadian, nepi ka para siswi loba nu dipecat ti sakola nagri. Nu matak. kacida bandeueulna mah aya sawatara ulama nu ngandang gelar profesor atawa doktor ngalesotkeun maneh tina surat al-Ahzab ayat 59. Cenk. nu saurang jilbab teh pakean impor ti Timur Tengah, dina Islam mah teu aya jilbab. Ceuk nu saurang deui kurudung teh pikeun nutupan dada lain pikeun nutupan sirah da dina surat an-Nur ayat 31 kieu unggelna: "Jeung maranehna kudu nutupan dadana make kurudung." Piraku nu geus nyandang gelar sarjana jeung ulama teu ngarti kana fungsi kurudung atawa tiung. Maksud ayat di lubur teh pasti kudu nutupan sirah terus sing ngarumbay nutupan dadana." QS: Al-A'rāf/7: 175; Hasim, Ayat Suci Lenyepaneun, vol. 9, pp. 221-2. 
The Satan has never been in doubt to lead a person astray, both the lay and religious (clergy) persons, let alone those whose faith is weak. The Satan who came and seduced clergy persons is "the Superior General of Satan". Let alone when the clergy is bribed by huge of money... and those who are presumed as a strong faith person (kyai), was finally tempted. The symbolic Satan said: "If the clergy (ama ajengan) issued a religious fatwa to allow female Muslim to take their jilbāb off, my friends and I will help to renovate the mosque", 68

Since several years ago up to the present, Muslims particularly female Muslims were slandered with malicious intent. Firstly, several students at SMA 3 (Senior High School 3) in Bandung were banned from wearing jilbāb by their sport teachers. It was followed by issuing prohibition laws to wear jilbab in school by the Ministry of Education and several female students in several cities were expelled from their schools. The reason as such was that wearing jilbāb violated the schools' rules. In responding to this issue, the Islamic scholars (ulama) were divided into three groups. The first group (minority) agreed and supported the government policy to bann jilbāb. Among them was argued that jilbāb was not an Islamic dress and was imported culturally from the Middle Eastern countries. There was even a silly argument saying: "instruction to wear jilbäb is only for those who intend to go to the toilet". It is sad to say that there are Islamic scholars who bravely resisted God's command on wearing jilbäb as stated in the Quran chapter al-Aḥzāb verse 59 and chapter an-Nūr verse 31. The second group of ulama was not in a clear position. They neither rejected the policy nor accepted it. They could be considered as an opportunistic group or nanglu (Sundanese language) people who would take advantage of the situation. The third group are those who are struggling to reject the policy and clarify the Fitnah with their thinkings. In this situation, there are people who hate Islam by spreading negative issues saying that

${ }^{68}$ The original version in Sundanese reads: Setan mah tara mangmang rampang-reumpeung boloampar ka nu ipis iman dalab ka ulama nu takwa ge tara asa-asa. Setan nu datang ka jalma nu takwa mah jendralna... Komo lamun disodoran amplop kandel atawa ditembongan gambar manuk. cendrawasib sabeungkeut gede dalah nu disangka kandel imanna ge loba nu leeh, mangkaning masjid geus mulan-malen rangkay bae da heureut pakeun tea. "Upama ama keresa ngaluarkeun fatwa ngahalalkeun kaom muslimat ngalesotkeun jilbab atanapi tiung, abdi sarerencangan parantos paheut sumeja nyanggakeun pangdeudeul sasieureun sabeunyeureun," nyaritana kitu teh bari nyodorkeun bungkusan. Jalma nu takwa upama lat poho lantaran kausap sagolongan setan nepi ka rek wani nukeurkeun iman kana ruruba, harita keneh bakal eling terus istighfar." QS: Al-A'rāf/7: 201; Hasim, Ayat Suci Lenyepaneun, vol. 9, p. 291. 
there are veiled Muslims who poisoned food on sale in the traditional market. Due to this issue, a Muslim female was killed by a crowd without reasons. Thus, Muslim scholars should bravely follow the Quranic teachings on jïhäd as stated at chapter al-Anfāl. To fight for the fitna (slander), we should consider the situations and conditions and for those who are in power, they should use their power to save Islam and Muslims. The kyai and their followers should argue against infidels' propaganda and Muslim scholars should criticize UUD (Undang-Undang Dasar/Indonesian constitution) that protects freedom to implement Islamic religious teachings. ${ }^{69}$

\section{Critique on Corruption and Social-Gap in Society}

In addition to lottery and julbäb's issues, Hasim also criticized the New Order regime of the political corruption, and of permitting the ruling elites and conglomerates in making a wider social-gap among

${ }^{69}$ The original version in Sundanese reads: "Ti mimiti sawatara taun nu geus kaliwat tug nepi ka kiwari, ummat Islam bususna kaom Muslimat geus dikiruban ku fitnah. Mimitina muridmurid SMA 3 Bandung dilarang make jilbab ku guru olabraga. Nyusul larangan ti Depdikbud, saterusna sababaraha siswi SMAN nu marake jilbab di sawatara kota dikaluarkeun ti sakola. $\mathrm{Nu}$ jadi alesan cenab ngalanggar aturan sakola.

Kaom ulama paturay jadi tilu golongan, golongan leutik ngadeudeul kaputusan Depdikbud, di antarana aya nu nyebutkeun yen jilbab teh lain busana Islam tapi busana nu diimpor ti Timur Tengah, jeung aya deui nu nyebutkeun yen tiung teh pikeun nutupan beubeung. Malab aya nu aneh kacida pokna teh: "Kudu dijilbab soteb lamun rek indit ka WC." Teungteningeun para ulama plus nepi ka wani ngalawan kana dawuban Allah SWT dina surat al-Abzab ayat 59 jeung surat anNur ayat 31.

Ulama golongan kadua mah cuci tangan atawa wandu, nyebut ngewa henteu ngabela benteu, ieu mah sigana kaasup golongan nanglu supaya bisa mibapekeun beuteung. Ari golongan katilu mab benerbener teuneung ludeung makalangan merangan fitnah sabudi akal. Kabehdieunakeun mah aya nu nista luar biasa, jalma-jalma nu ngabenci Islam nyebarkeun taleus ateul majarkeun teb nu marake jilbab ngaracun sawatara rupa bahan kadaharan nu didagangkeun di pasar, nepi ka aya kaom Muslimat nu dikoroyok teu pupuguh. Ieu teh fitnah nu ngabalukarkeun jalma-jalma nu teu tuah teu dosa ngarandapan panandasa. Ari nu jadi tujuanana salian ti rek ngancurkeun agama Islam, oge rek ngaririweuh Pamarentah. Ku sabab eta sakuduna mah para ulama, para kiai atawa ajengan teh tandang ngalaksanakeun timbalan Allah SWT nu kaunggel dina bubuka ayat 39 ieu.

Merangan fitnah teh kudu saluyu jeung situasi sarta kondisi, nu baroga kakawasaan wajib ngagunakeun kakawasaanana pikeun numpes fitnah, para kiai katut panganutna wajib nakis propaganda kaom kafirin ku ayat-ayat suci saperti ayat 59 surat al-Abzab jeung ayat 31 surat anNur, atub golongan cendikiawan wajib ngagugat UUD nu ngajamin kabebasan dina ngalaksanakeun agama." QS: Al-Anfāl/8: 39; Hasim, Ayat Suci Lenyepaneun, vol. 9, pp. 385-6. 
societies. In interpreting the Quran chapter Al-Ma'idah [5]: verse 85 and 94, for example, Hasim said:

People, who are not grateful for God's blessing, only want a temporary pleasure. Conglomerates cooperated with the greedybureaucrats, collected money for worldly happiness and they forgot the prosperous life of their decendents who will be living in the future. ${ }^{70}$

In the present days, there are huge temptations influencing people's heart and faith (imān). When they turned their face to North, they saw luxurious buildings and hotels; looked on other side, they saw luxurious cars and expensive clothes. While in fact, we should live in a humble and modest manner. That is a trusted bureaucrat or leader. When we are in a poor condition, the manipulation or corruption door will be opened. This is a real ordeal from God. When our belief or faith is weak and we pursue our desire for temporary happiness in the world; we should be aware of the fact that God will punish with a very painful torment in the hereafter. ${ }^{71}$

Hasim's critiques of corruption and social-gap issues in the society, have been explained by Hasim when he interpreted the Quran chapter Al-A'rāf/ 7 verse 92 and 125 as follows:

Greedy people in present days ate everything. Their greed has spoiled the nature. A collusion between conglomerate and bureucrate has caused the deforestation and severe degradation of the mountains. Consequently, it leads to flood during the rainy seasons and drought during the summer. It is very common that at the end, the poor people will be ones mostly affected. And the

\footnotetext{
70 The original version in Sundanese reads: Manusa anu kufur kana nikmat Ilabi mangpangmeungpeung hayang senang sakeudeung, kaom konglomerat nu sakongkol jeung kaom birokrat geus kabengbat ku dunya pupulasan nepi ka poho kana karaharjaan rundayan nu bakal rumingkang dina jaman nu bakal datang. Hasim, Ayat Suci Lenyepaneun, vol. 7, p. 9.

71 The original version in Sundanese reads: Jaman ayeuna loba pisan gogoda nu matak marudah bate jeung ngagoncangkeun iman. Ret ngaler nenjo gedong sigrong, ngalirik ka gigir breh mobil mewah, jrat-jrut nu tarurun pakean paginding-ginding burung nangtung siang leumpang, ari beug urang sanajan birup ngirit sairit-iritna lamun bisa tilas tepus ge geus untung. Kitu ninggang di jelema jujur sanajan jadi pajabat. Dina kaayaan heureut pakeun panto manipulasi dikemplongkeun, tah ieu teh ujian ti Pangeran. Lamun iman kabawa palid ku sasalad sumput salindung, ngarempak wates wangen milu curak-curak jeung nu teu aleucreng, senang-senang sakeudeung di alam fana, engke di aherat pasti pinanggih jeung ceurik getih nandangan siksaan nu nyeri taya papadana. Hasim, Ayat Suci Lenyepaneun, vol. 7, p. 39.
} 
ruling bureucrate easily blamed the people saying that "it is your mistake to build a house close to a river". ${ }^{72}$

It could be said that in current days, there are many Pharaoh's decendents in the country because there were many empty promises delivered by the ruling government. The government said from the people to the people; but in fact, the people's lands were taken and robbed by the conglomerates. ${ }^{73}$

From the discourse-analysis perspective, Hasim was sucsessful in showing social critiques to New Order policies through his interpretation of Quranic text mechanism. For sure, Hasim did not neglect the socio-religious context around the text. ${ }^{74} \mathrm{He}$ showed an ideological interest inserted behind the text in writing the tafsir. Hasim insisted the availability of power contestation existed in the production or reproduction of meaning. Hasim could not be seen as a neutral writer who could freely interpret the Quranic text according to his own thinking because it could be influenced by the socio-political context which existed in the society. In this context, language could be understood as a representation that has a role to create a special subject, and particular themes of discourse, including its strategy.

When the critical responses of writer in interpreting Quranic verses were in line with the social reality of the writer, the Quranic studies called it as an adabi ijtimát $i$ (socio and cultural) approach. This kind of approach tried to uncover the Quranic messages related to social issues and tried to answer social problems by interpreting the Quranic texts, which is easily understood by the readers. ${ }^{75}$ This kind of tafsir seems to be very critical to respond to social problems as they appeared in the

\footnotetext{
72 The original version in Sundanese reads: Kasarakaban manusa jaman ayeuna, nu gembul sagala beuki, geus mimiti nimbulkeun tanda-tanda kabinasaan. Kolusi antara konglomerat jeung kaom birokrat ngabalukarkeun gunung-gunung jadi garundul, leuweung luang-liwung jadi bolenang, balukarna datang bujan babanjiran, datang katiga tigerat ku cai. Geus biasa nu katideresa mah ra'yat nu teu walakaya, nya kateumbleuban geugeuleub nya nanggung balukarna. Abong letah teu tulangan, ceuk nu dibendo: "Salah maraneh sorangan, bongan sok nyeser sisi solokan." Hasim, Ayat Suci Lenyepaneun, vol. 9, p. 12.

73 The original version in Sundanese reads: Sigana jaman kiwari ge rundayan Fir'aun teh rada loba upama ngabandungan jangji-jangij kosong molongpong nu sok diobral ka para orator mah. Majah maneh dari rakyat untuk rakyat buktina mah tanah garapan rakyat dirampas ku konglomerat. Hasim, Ayat Suci Lenyepaneun, vol. 9, p. 92.

${ }^{74}$ Eriyanto, Analisis Wacana, Pengantar Analisis Teks Media (Yogyakarta: LKiS, 2001), p. 7.

${ }^{75}$ M. Quraish Shihab, Membumikan Al-Qur'an (Bandung: Mizan, 1996), p. 68.
} 
societies. Thus, the existence of the tafsir could not be ignored in describing socio-religious epistemé of the existed society. In the words of Woodward, the text of the tafsir could have a particular function as a medium to deliver critiques on socio-religious situation of society. ${ }^{76}$ The tafsir could also be considered as a mirror of social change happening in a particular era of society. ${ }^{77}$

In other words, the Lenyepaneun tafsir reflected a strong connection between Hasim (the writer) with the main problems of interpretation that is how to relate the Quranic texts with the historical, social, political and intellectual context. In Gadamer's concept, this is called the fusion of horizons that is the horizon of text and the horizon of the interpreter or writer. The interpreter tries to bring his understanding as close as possible to the sphere of the text and the text at the same time was understood from the interpreter's perspective. ${ }^{78}$

In the Quranic studies tradition, scholars such as Al-Dhahabī, AlFarmawī and 'Alī 'Iyazī have very well mapped the kind of tafsir which can be used to examine the position of tafsir in its long tradition. ${ }^{79}$ They generally categorized or divided the kind of tafsir into the method (al-tariqab), approach (manhaj), characteristics (al-lawn) and orientation (al-ittijah) of the tafsir. The Lenyepaneun tafsir seems to be dominated by horizon insights and knowledge of the writer (Hasim) on sociopolitical context of the New Order in which the writer has been living. Hasim's critques of the New Order's policies could become very important indicators to show that his tafsir was using socio-political and cultural approach (al-adab al-ijtima' $\bar{\imath})$.

\footnotetext{
${ }^{76}$ Mark R. Woodward, “Textual Exegesis as Social Commentary: Religious, Social, and Political Meanings of Indonesian Translations of Arabic Hadith Texts," The Journal of Asian Studies, 52, 3 (1993), p. 565.

77 Wan Sabri Wan Yusof, "Hamka's Tafsir al-Azhar: Qur'anic Exegesis as a Mirror of Social Change," Unpublished Ph.D Thesis, Temple University, Philadelphia (1997), p. 36.

${ }^{78}$ Hans Georg Gadamer, Truth and Method (New York: Continuun, 2004), p. 299.

${ }^{79}$ Muhammad Husain Al-Dzahabi, Al-Tafsì wa al-Mufassirūn (Kairo: Al-Babi al-Halabi, n.d.), vol. 2; Abd al-Hay al-Farmawy, al-Bidāyät fi al-Tafsìr al-Maudhü'i (Mesir: Maktabah Jumhuriyah, 1977); Muhammad 'Ali Iyazi, al-Mufassirūn Hayātubum wa Manhäjubum (Teheran: Mu’assasah al-Tiba'iyah wa Nasyr Wizarah al-Tsaqafah al-Islamiyah, 1994).
} 


\section{Conclusion}

The New Order government showed their interest to 'politicize' religion through the establishment of religious institution. Soeharto developed an idea called development ideology. Islam was put under the development framework. During the New Order Era, the state used religious patronage (such as MUI and mass Muslim organizations) to maintain loyality of people to the state. The Soeharto's government urged religions to have more significant roles in socio and cultural aspects instead of politics. This policy affected the Islamic role in the country be that political and cultural. The Soeharto's regime seems to combine between repressive and tolerant approaches as well as coercive and cooperative approaches to control various religious expressions of the Muslim society in the country. The policy and religious discourse created by the New Order regime to control Muslims in Indonesia was criticized and responded critically by Hasim through his texts of Lenyepaneun tafsir.

Moh. E. Hasim or Mohammad Emon Hasim was popularly known as a teacher, a Muhammadiyah activist, as well as a tafsir writer. He spoke Arabic, English, Japanese and Dutch very well. He never studied Islamic teaching in Islamic boarding school. He studied languages (including Arabic) and Islamic teachings autodidactically instead. He wrote several tafsir including Lenyepaneun tafsir (1990-1993).

The tafsir of Ayat Suci Lenyepaneun could be considered as the first Sundanese tafsir written in roman script and a very complete one in terms of content (covered all 30 chapters of the Quran). This tafsir used sentences (languages) which are very easily understood by the readers. The tafsir begins by citing Quranic text written in Arabic followed by roman text and translation. The writer translated Arabic text word by word followed by roman script and detailed explanation of the texts. In its methodology, Hasim uses the rational approach known as tafsir bi al-ra'y and the tabliti method through which he interprets the Quran following the established-Quranic verses' order. This tafsir shows its distinction as a Sundanese tafsir not only as a local tafsir in West Java using Sundanese literatures, but also shows its special characteristic of Hasim's responses to social, political and religious context where the writer lives.

In his Lenyepaneun tafsir , Hasim comprehensively responded to the socio-religious discourses debated in the new Order era between 1980s-1990s. He even criticised the regime. For example, Hasim 
sharply criticised the policy of Soeharto's New Order government that legalized soccer lotto, called Porkas and Sumbangan Dana Sosial Berbadiah (SDSB/Social fund Donation Prizes). He also criticized the fatwa of ulama that supported the policy of Soeharto's regime. In the New Order era, Hasim also criticized the government's policy to ban Muslim's students from wearing veil (jilbäb) in schools. Corruption, collusion between the government officials and businessmen conglomerates and the social-economic gap among Indonesian people during the New Order Era were criticized by Hasim.

This study shows that Quranic interpretation (exegesis) or tafsir does not only deliver religious values of the Quran to the readers, but also demonstrates a dialectical process of the interprter with the sociopolitical situations he faced while writing the tafsir. Hasim delivers his critical voices to build a bridge between a holy-God verses, locality and socio-historical context around the readers. Hasim's critical voices are important to be identified in order to show that there was a very strong unsatisfied Muslim in Indonesia to the New Order policies, even to the fringe area such as the Sundanese people who live in the villages of West Java.]

\section{References}

\section{Books and Articles}

Alifah, Laily. "Pandangan Moh. E. Hasim Mengenai Syirik dan Unsurunsurnya dalam Budaya Sunda". Unpublished BA Thesis, UIN Sunan Gunung Djati, Bandung, 2016.

Azra, Azyumardi. "Islam Nusantara: Islam Indonesia". Republika, 25 June 2015.

. "The Transmission of al-Manar's Reformism to the MalayIndonesian World: The Case of al-Imäm and al-Munir'. Stephane A. Dudoignon, Komatsu Hisao, and Kosugi Yasushi (eds). Intellectuals in the Modern Islamic World. New York: Routledge, 2006.

Baidan, Nashruddin. Perkembangan Tafsir Al-Qur'an di Indonesia. Solo: Tiga Serangkai, 2003.

Bowie, Fiona, The Anthropology of Religion, An Introduction. Oxford: Blackwell Publishers, 2001. 
Burhanudin, Jajat. "Aspiring for Islamic Reform: Southeast Asian Requests for Fatwa in al-Manär". Islamic Law and Society, 12, 1 (2005).

Al-Dzahabi, Muhammad Husain. Al-Tafsîr wa al-Mufassirûn. Cairo: AlBabi al-Halabi, n.d.

Eklof, Stefan. Indonesian Politics in Crisis: The Long Fall of Subarto 19661998. Copenhagen: Nordic Institute of Asian Studies, 1999.

Eriyanto. Analisis Wacana, Pengantar Analisis Teles Media. Yogyakarta: LKiS, 2001.

Al-Farmawy, Abd al-Hay. al-Bidâyat fi al-Tafsîr al-Maudbûंi. Mesir: Maktabah Jumhuriyah, 1977.

Federspiel, Howard M. Popular Indonesian Literature of the Qur'an. Ithaca, New York: Cornell Modern Indonesia Project, no.72, 1994.

Francese, Joseph. (ed.). Perspectives on Gramsci, Politics, Culture and Social Theory. New York: Routledge, 2009.

Gadamer, Hans Georg. Truth and Method. New York: Continuun, 2004.

Gusmian, Islah. Khazanah Tafsir Indonesia. Jakarta: Teraju, 2002.

--------. "Tafsir Al-Qur'an dan Kritik Sosial: Dinamika Tafsir AlQur'an di Indonesia”. Maghza, 1, 2 (2016).

. "Tafsir Al-Qur'an dan Kekuasaan: Menelusuri Jejak Dialektika Tafsir Al-Qur'an dan Praktik Politik Rezim Orde Baru”. Paper of Annual International Conference on Islamic Studies (AICIS) XIV, Balikpapan, 21-24 November 2014.

Hamka. Tafsir al-Az̧ar. Jakarta: Pustaka Panjimas, 1983.

Hasim, Moh. E. Ayat Suci Lenyepaneun. Bandung: Pustaka, 1994.

------. Rupa-rupa Upacara Adat Sunda Jaman Ayeuna. Bandung: Pustaka, 1996.

-------. Hadis Penting Papadang Ati. Bandung: Pustaka, 1997.

. Ayat Suci dalam Renungan 30 Jilid. Bandung: Pustaka, 1998.

-----. Khatbah Shalat Juma'ah. Bandung: Pustaka, 2006.

Hassan, A. Tafsir Al-Foerqan Tafsir Qer'an Basa Soenda. Compiled by Djoeragan Mh. Anwar Sanuci and Djoeragan Mh. Doenaedi. Bandung: Taman Poestaka Persatoean Islam, Januari 1929. 
Hefner, Robert W. Civil Islam: Muslim and Democratization in Indonesia. Princeton and Oxford: Princeton University Press, 2000.

Heryanto, Ariel. Perlawanan dalam Kepatuhan. Bandung: Mizan, 2000.

Ibrahim, Sulaiman. "Tafsir Al-Qur'an Bahasa Bugis: Vernakularisasi dalam Kajian Tafsir al-Munir". Unpublished Doctoral Thesis, UIN Syarif Hidayatullah, Jakarta, 2012.

Iskandar, Megah. "Tema Tauhid dalam Tafsir Ayat Suci Lenyepaneun karya Moh. E. Hasim". Unpublished BA Thesis, UIN Sunan Gunung Djati, Bandung, 2007.

Iyazi, Muhammad 'Ali. al-Mufassirun Hayatuhum wa Manbajubum. Teheran: Mu'assasah al-Tiba'iyah wa Nasyr Wizarah al-Tsaqafah al-Islamiyah, 1994.

Junaidi, Akhmad Arif. "Tafsir Al-Qur'an Al-Azhim Karya Raden Pengulu Tafsir Anom". Unpublished Doctoral Thesis, IAIN Walisongo, Semarang, 2012.

Laraswati, Nadia. "Budaya Sunda dalam Tafsir Ayat Suci Lenyepaneun Karya Moh. E. Hasim". Unpublished BA Thesis, UIN Sunan Gunung Djati, Bandung, 2016.

Miles, Mathew B. and A. Michael Huberman. Analisis Data Kualitatif: Buku Sumber tentang Metode-metode Baru. Jakarta: UI Press, 1992.

Muchoyyar HS, M. "KH. Muhammad Shalih Al-Samarani: Studi Tafsir Faid Al-Rahman fi Tarjamah Tafsir Kalam Malik Al-Dayyan". Unpublished Doctoral Thesis, UIN Sunan Kalijaga, Yogyakarta, 2000.

Muhammad, Afif. Dari Teologi ke Ideologi, Kajian terhadap Gagasan dan Pemikiran Teologi Sayyid Quthb. Bandung: Pena Merah, 2004.

Muhsin, Imam. "Tafsir Al-Qur'an dan Budaya Lokal: Nilai-nilai Budaya Jawa dalam Tafsir Al-Huda Karya Bakri Syahid”. Unpublished Doctoral Thesis, UIN Sunan Kalijaga, Yogyakarta, 2008.

Njoto-Feillard, Gwenael. "Ripples from the Middle East: The Ideological Battle for the Identity of Islam in Indonesia," Pesrpective. 42. Singapore: ISEAS Yusof Ishak Institute, 2015.

Nurlaela, Aan. Makna Kafir Menurut Para Mufasir Indonesia (Studi Analisa Tafsir Moh. E. Hasim, Hasbi Ash-Shiddieqy, Quraish 
Shihab". Unpublished BA Thesis, UIN Sunan Gunung Djati, Bandung, 2016.

Quthb, Sayyid. Fi Zhilal al-Qur'an. Beirut: Dar al-Syuruq, 1988.

Rafiq, Ahmad. "The Reception of the Qur'an in Indonesia: A Case Study of the Place of the Qur'an in a Non-Arabic Speaking Community". Unpublished PhD Thesis, Temple University, Philadelphia, 2014.

Redfield, Robert. Peasant Society and Culture, An Anthropological Approach to Civilization. Chicago: The University of Chicago Press, 1956.

Reid, Anthony. Imperial Alchemy, Nationalism and Political Identity in Southeast Asia. Cambridge: Cambridge University Press, 2009.

Ridha, Al-Sayyid Muhammad Rasyid. Tafsir al-Qur'an al-Hakim alMusytahar bi ism Tafsir al-Manar. Kairo: Mansya al-Manar, 1947.

Robison, Richard. Indonesia: The Rise of Capital. Sydney: Allen and Unwin Pty Ltd, 1986.

Rohmana, Jajang A. 'Nilai Budaya dalam Tafsir Al-Qur'an Berbahasa Sunda". Unpublished Doctoral Thesis,UIN Sunan Gunung Djati, Bandung, 2013.

-------. "Perkembangan Kajian Al-Qur'an di tatar Sunda: Sebuah Penelusuran Awal". Jurnal Subuf, 6, 1 (2013).

. "Ideologisasi Tafsir Lokal Berbahasa Sunda: Kepentingan Islam-Modernis dalam Tafsir Nurul-Bajan dan Ayat Suci Lenyepaneun". Journal of Qur'an and Hadith Studies, 2, 1 (2013).

--------. “Al-Qur’ān wa al-Istímār: Radd al-Shaykh al-Hāīj Ahmad Sanusi (1888-1950) 'alá al-Isti'mār min Khilāl Tafsīr Malja' alTälibin’. Studia Islamika, 22, 2 (2015).

Romli, Mhd. And H.N.S. Midjaja. Nurul-Bajan: Tafsir Qur'an Basa Sunda. 1, N.V. Perboe (1966).

Romli, Muhammad. Al-Kitabul Mubin Tafsir Basa Sunda. Bandung: PT. Al-Ma'arif, 1991.

Ronald, Nettler. "A Modern Islamic Confession of Faith and Conception of Religion: Sayyid Quthb's Introduction to the Tafsir Fi Zhilal al-Qur'an". British Journal of Middle Eastern Studies, 21, 1 (1994). 
Rosidi, Ajip. (ed.). Ensiklopedi Sunda, Alam, Budaya, dan Manusia. Jakarta: Pustaka Jaya, 2000.

Rosyadi, Teten. Tafsir Ayat-Ayat Pendidikan dalam Kitab Tafsir Berbahasa Sunda: Sebuab Kajian terhadap Tafsir Ayat Suci Lenyepaneun Karya Moh. E. Hasim." Unpublished BA Thesis, Universitas Ibnu Khaldun, Bogor, 2014.

Sanuci, Moehammad Anwar. Gajatoel-Bajan Tafsir Qoer'an Basa Soenda. Garut: Madjlis Ahli Soennah Garoet, 1923.

Sanusi, Ahmad. Malja' al-Thâlibîn, Tapsir bahasa Soenda, No 1-28. Tanah Tinggi Senen No. 191 Batavia Kramat. 1931/1349 H.

Sardar, Ziauddin. "The Future of Islamic Studies". Islamic Culture 57 (1983).

Shepard, William E. "Sayyid Quthb's Doctrine of Jabiliyya". International Journal of Middle East, 35 (2003).

Shihab, M. Quraish. Studi Kritis Tafsir al-Manar. Bandung: Pustaka Hidayah, 1994.

------. Membumikan Al-Qur'an. Bandung: Mizan, 1996.

Sirry, Mun'im. "What's modern about tafsir? A Closer look at Hamka's Tafsir al-Azhar". Majid Daneshgar et.al. The Qur'an in the MalayIndonesian World: Context and Interpretation. New York: Routledge, 2016.

Suganda, Her. "Moh. E. Hasim, Berkarya Sampai Tua”. Kompas, 13 July 2004.

Suhendar. "Penafsiran Moh. E. Hasim terhadap Ayat-ayat Syirik Samar dalam Tafsir Lenyepaneun". Unpublished BA Thesis, UIN Sunan Gunung Djati, Bandung, 2004.

Suhendar, Uu. Tafsir Al-Rari Juz 'Amma jeung Al-Fatibah, Kasaluyuan Surat, Ayat jeung Mufrodat. Tasikmalaya: Pustaka Al-Razi, 2011.

Taufiq Qurrahman, Rifki. "Pembinaan Akhlak Anak Perspektif AlQur'an (Penafsiran Moh. E. Hasim Surat Luqman Ayat 13-19)". Unpublished BA Thesis, UIN Sunan Gunung Djati, Bandung, 2016.

Wan Yusof, Wan Sabri. "Hamka's Tafsir al-Azhar: Qur'anic Exegesis as a Mirror of Social Change". Unpublished Ph.D. Thesis, Temple University, Philadelphia, 1997. 
Woodward, Mark R. "Textual Exegesis as Social Commentary: Religious, Social, and Political Meanings of Indonesian Translations of Arabic Hadith Texts". The Journal of Asian Studies. 52, 3 (1993).

Yusuf, Milhan. "Hamka's method in interpreting legal verses of the Qur'an". Abdullah Saeed (ed.). Approaches of the Qur'an in Contemporary Indonesia. London: Oxford University Press in association with the Institute of Ismaili Studies, 2005.

Yusuf, M. Yunan. Corak Pemikiran Kalam Tafsir al-Az̧har. Jakarta: Pustaka Panjimas, 1990.

Zarkasyi, Jaja. "Bahasa Sunda dalam Penafsiran Al-Qur'an". Unpublished MA Thesis, UIN Syarif Hidayatullah, Jakarta, 2009.

Zimmer, Benjamin G. "Al-'Arabiyyah and Basa Sunda: Ideologies of Translation and Interpretation among the Muslims of West Java". Studia Islamika, 7, 3 (2000).

Zuhdi, M. Nurdin. Pasaraya Tafsir Indonesia: Dari Kontestasi Metodologi Hingga Kontekstualisasi. Yogyakarta: Kaukaba Dipantara, 2014.

\section{Interview}

Interview with Halimah (66 years old), third daughter of Hasim, Bandung, 06 February 2017. 